\title{
Length and Biomass Data for Atlantic and Pacific Seaweeds From Both Hemispheres
}

\author{
Ricardo A. Scrosati ${ }^{1 *}$, Heather L. MacDonald ${ }^{1}$, César A. Córdova ${ }^{2}$ and Graciela N. Casas $^{3}$ \\ ${ }^{1}$ Department of Biology, St. Francis Xavier University, Antigonish, NS, Canada, ${ }^{2}$ Facultad de Ciencias Biológicas, Universidad \\ Nacional Mayor de San Marcos, Lima, Peru, ${ }^{3}$ Instituto de Biología de Organismos Marinos, Centro Nacional Patagónico, \\ Puerto Madryn, Argentina
}

Keywords: algae, allometry, biomass, intertidal, length, seaweed

\section{INTRODUCTION}

As the length of an organism is a unidimensional measure but its biomass is distributed across three dimensions, length and biomass are allometrically related in plants and animals. Due to the high interspecific morphological variation in nature (e.g., long, thin, and narrow flatworms vs. short and globose snails), the biomass-length relationship differs among species. Interest in the principles governing biomass-length allometry has sparked research about the drivers of biological form

Edited by:

Pedro Morais,

University of Algarve, Portugal

Reviewed by:

Alejandro H. Buschmann,

University of Los Lagos, Chile

Leonel Pereira,

University of Coimbra, Portugal

Renato Crespo Pereira,

Fluminense Federal University, Brazil

*Correspondence:

Ricardo A. Scrosat

rscrosat@stfx.ca

Specialty section:

This article was submitted to Marine Biology,

a section of the journal

Frontiers in Marine Science

Received: 07 August 2020

Accepted: 11 September 2020

Published: 26 October 2020

Citation:

Scrosati RA, MacDonald HL,

Córdova CA and Casas GN (2020) Length and Biomass Data for Atlantic

and Pacific Seaweeds From Both

Hemispheres.

Front. Mar. Sci. 7:592675.

doi: $10.3389 /$ fmars.2020.592675
(West et al., 1999; Niklas and Enquist, 2001; Makarieva et al., 2005; Kleyer et al., 2019). Biomasslength allometry can ultimately be of practical value, such as for the non-destructive estimation of stand biomass (Scrosati, 2006a; Yuen et al., 2016) and productivity (Martin et al., 2014), the determination of body condition (Brodeur et al., 2020), or the unintrusive estimation of body mass (Turnbull et al., 2014; Coulis and Joly, 2017; Sohlström et al., 2018), which is in turn allometrically related to various biological processes (Brown et al., 2004; Marquet et al., 2005).

Marine macroalgae, or seaweeds, are morphologically diverse (Steneck and Dethier, 1994), so there are interspecific differences in biomass-length allometry. Due to the importance of biomasslength allometric relationships, the objective of this paper is to provide unpublished datasets for species representing the three major seaweed groups: the red (Rhodophyta), brown (Ochrophyta, Phaeophyceae), and green (Chlorophyta) algae. We describe the biomass-length allometry of species representing both hemispheres and two oceans (Atlantic and Pacific).

As for vascular plants (de Kroon and van Groenendael, 1997), in seaweeds there are clonal and unitary species. A clonal seaweed is that in which its holdfast (the structure that keeps the thallus attached to the substrate) produces a number of fronds that have the ability to live independently if separated from the rest of the thallus as long as the frond remains attached to the substrate by holdfast tissue (see photos of clonal seaweeds in Scrosati, 2005). The holdfast tissue of such an isolated frond can grow across the substrate and, in turn, produce new fronds. Thus, fronds of clonal seaweeds are ramets (a term originally developed for shoots of clonal vascular plants; de Kroon and van Groenendael, 1997), while the entire thallus (holdfast and fronds) that develops from one spore, zygote, or parthenogenetic gamete is the genet (Scrosati, 2002a). A unitary seaweed only produces one frond from its holdfast (Scrosati, 2005). While demographic studies are done at the level of the individual for unitary seaweeds, they are typically done at the level of the frond for clonal seaweeds, as fronds are easy to count and, ultimately, are the structures that develop reproductive tissues and provide biomass readily available for consumers (Rivera and Scrosati, 2008; Cetz-Navarro et al., 2015; Pereira et al., 2017). Therefore, in this paper, length and biomass are reported for fronds for clonal species and for individuals for unitary species. 


\section{MATERIALS AND METHODS}

In this article, length data are expressed in $\mathrm{cm}$, while biomass data represent dry biomass expressed in $\mathrm{mg}$ (Scrosati et al., 2020). Since most of the measured algae were collected during low tides in rocky intertidal habitats (see below), some degree of desiccation had taken place prior to collection. Even the subtidal algae (collected under water) may have experienced some mild desiccation between the time of collection and the time of measurements in the lab, because they were transported in bags without water to the lab. Thus, to ensure uniformity in the data, all collected algae were submerged in seawater in the lab until reaching full hydration before their length was measured. To measure their dry biomass, we followed one of two approaches. For some species (see below), we dried the collected algae in the oven at $60^{\circ} \mathrm{C}$ until constant mass (dry biomass) was reached, which allowed us to measure the dry biomass of each collected specimen. For other species (see below), we first blotted dry the fully hydrated specimens to remove surface moisture and then we measured their wet biomass. Then, we estimated their dry biomass by multiplying their wet biomass by the corresponding species-specific ratio of dry biomass to wet biomass, previously calculated as the average of the ratio of dry biomass to wet biomass measured for a separate sample of specimens.

The following paragraphs provide information for the studied species listed alphabetically. The scientific names were checked in August 2020 using AlgaeBase (Guiry and Guiry, 2020). Photographs of these species are available from AlgaeBase. The initials correspond to this article's authors. The species from Canada, Peru, and Argentina are from temperate environments, while the species from Mexico is from a subtropical environment. The studied species were:

Alaria esculenta (Linnaeus) Greville (Phaeophyceae, Laminariales). Individuals of this unitary species were collected by HLM in shallow subtidal habitats from Tor Bay Provincial Park, on the open Atlantic coast of Nova Scotia, Canada, on 10 August 2006. The dry biomass of each individual was calculated by multiplying its wet biomass by a species-specific ratio of dry biomass to wet biomass of 0.232977 obtained by HLM.

Ascophyllum nodosum (Linnaeus) Le Jolis (Phaeophyceae, Fucales). Fronds of this clonal species were collected by HLM at high, middle, and low elevations in rocky intertidal habitats subjected to low and moderate wave exposure in Tor Bay Provincial Park, Nova Scotia, Canada, on 10 August 2006. The dry biomass of each frond was calculated by multiplying its wet biomass by a species-specific ratio of dry biomass to wet biomass of 0.315531 obtained by HLM. These intertidal beds were later used for a study that evaluated the effects of intertidal macroalgal canopies on benthic biodiversity depending on environmental stress (Watt and Scrosati, 2013).

Asterfilopsis furcellata (C. Agardh) M. S. Calderon \& S. M. Boo (Rhodophyta, Gigartinales). Fronds of this clonal species were collected by CAC in rocky intertidal habitats from Ancón Bay, on the Pacific coast in central Peru, on 17 April 2007. Dry biomass was measured for each collected frond by drying the fronds to constant mass in an oven.
Chondrus crispus Stackhouse (Rhodophyta, Gigartinales). Fronds of this clonal species were collected by RAS at low elevations in rocky intertidal habitats from Tor Bay Provincial Park, Nova Scotia, Canada, on 31 July 2004. The dry biomass of each frond was calculated by multiplying its wet biomass by a species-specific ratio of dry biomass to wet biomass of 0.239 obtained by RAS. The data hereby presented were used in a study that compared the interspecific length-biomass allometry for predominantly bidimensional seaweeds with that for microalgae and vascular plants (Scrosati, 2006b).

Chorda filum (Linnaeus) Stackhouse (Phaeophyceae, Chordales). Fronds of this species were collected by HLM in shallow subtidal habitats from Sea Spray Shore, on the Gulf of St. Lawrence coast of Nova Scotia, Canada, on 9 August 2006. The dry biomass of each frond was calculated by multiplying its wet biomass by a species-specific ratio of dry biomass to wet biomass of 0.171614 obtained by HLM.

Chordaria flagelliformis (O. F. Müller) C. Agardh (Phaeophyceae, Ectocarpales). Fronds of this species were collected by HLM at low elevations in rocky intertidal habitats from Sea Spray Shore, on the Gulf of St. Lawrence coast of Nova Scotia, Canada, on 12 July 2006. The dry biomass of each frond was calculated by multiplying its wet biomass by a species-specific ratio of dry biomass to wet biomass of 0.571474 obtained by HLM.

Fucus distichus Linnaeus (Phaeophyceae, Fucales). Individuals of this species were collected by HLM from high-intertidal tide pools in Tor Bay Provincial Park, Nova Scotia, Canada, on 10 August 2006. The dry biomass of each individual was calculated by multiplying its wet biomass by a species-specific ratio of dry biomass to wet biomass of 0.290165 obtained by HLM.

Fucus serratus Linnaeus (Phaeophyceae, Fucales). Individuals of this species were collected by HLM from shallow subtidal habitats on Sea Spray Shore, on the Gulf of St. Lawrence coast of Nova Scotia, Canada, on 9 August 2006. The dry biomass of each individual was calculated by multiplying its wet biomass by a species-specific ratio of dry biomass to wet biomass of 0.229087 obtained by HLM.

Fucus spiralis Linnaeus (Phaeophyceae, Fucales). Individuals of this species were collected by HLM at high elevations in rocky intertidal habitats from Grande Greve, on the Atlantic coast of Nova Scotia, Canada, on 20 July 2006. The dry biomass of each individual was calculated by multiplying its wet biomass by a species-specific ratio of dry biomass to wet biomass of 0.202924 obtained by HLM.

Fucus vesiculosus Linnaeus (Phaeophyceae, Fucales). Individuals of this unitary species were collected by RAS at middle and low elevations in rocky intertidal habitats from Tor Bay Provincial Park, Nova Scotia, Canada, on 16 August 2004. Only non-reproductive individuals (without receptacles) were collected. The dry biomass of each individual was calculated by multiplying its wet biomass by a species-specific ratio of dry biomass to wet biomass of 0.207 obtained by RAS. The data hereby presented were used in a study that compared the interspecific length-biomass allometry for predominantly bidimensional seaweeds with that for microalgae and vascular plants (Scrosati, 2006b). 
Grateloupia doryphora (Montagne) M. Howe (Rhodophyta, Halymeniales). Fronds of this clonal species were collected by CAC in rocky intertidal habitats from Ancón Bay, central Peru, on 17 April 2007. Dry biomass was measured for each collected frond by drying the fronds to constant mass in an oven.

Laminaria digitata (Hudson) J. V. Lamouroux (Phaeophyceae, Laminariales). Individuals of this unitary species were collected by HLM in shallow subtidal habitats from Tor Bay Provincial Park, Nova Scotia, Canada, on 10 August 2006. The dry biomass of each individual was calculated by multiplying its wet biomass by a species-specific ratio of dry biomass to wet biomass of 0.249657 obtained by HLM.

Mastocarpus papillatus (C. Agardh) Kützing (Rhodophyta, Gigartinales). Fronds of this clonal species were collected by RAS in rocky intertidal habitats from Acadia Beach, Vancouver, British Columbia, on the Pacific coast of Canada, on 8 April, 7 May, 6 June, and 7 July 2003. The dry biomass of each frond was calculated by multiplying its wet biomass by a speciesspecific ratio of dry biomass to wet biomass of 0.294 obtained by RAS. The data hereby presented were used in a study that investigated the temporal relationship between frond density and stand biomass in this species (Scrosati, 2006a).

Mazzaella parksii (Setchell \& N. L. Gardner) Hughey, P. C. Silva \& Hommersand (Rhodophyta, Gigartinales). Fronds of this clonal species were collected by RAS at high elevations in rocky intertidal habitats from the east side of Prasiola Point, in Barkley Sound, on the open Pacific coast of Vancouver Island, British Columbia, Canada, on 29 April and 5 December 1994 and on 30 January, 3 April, 21 May, 14 July, and 29 October 1995. The dry biomass of each frond was calculated by multiplying its wet biomass by a species-specific ratio of dry biomass to wet biomass of 0.28 (Scrosati and DeWreede, 1998). The data hereby presented were used in studies that investigated the population dynamics (Scrosati, 1998) and biomass-density relationships (Scrosati and DeWreede, 1997; Scrosati, 2000) of this species.

Neorubra decipiens (Montagne) M. S. Calderon, G. H. Boo \& S. M. Boo (Rhodophyta, Halymeniales). Fronds of this clonal species were collected by CAC in rocky intertidal habitats from Ancón Bay, central Peru, on 17 April 2007. Dry biomass was measured for each collected frond by drying the fronds to constant mass in an oven.

Polyides rotunda (Hudson) Gaillon (Rhodophyta, Gigartinales). Fronds of this clonal species were collected by HLM in shallow subtidal habitats from Arisaig, on the Gulf of St. Lawrence coast of Nova Scotia, Canada, on 9 August 2006. The dry biomass of each frond was calculated by multiplying its wet biomass by a species-specific ratio of dry biomass to wet biomass of 0.291158 obtained by HLM.

Pterocladiella capillacea (S. G. Gmelin) Santelices \& Hommersand (Rhodophyta, Gelidiales). Fronds of this clonal species were collected by RAS at middle elevations in waveexposed rocky intertidal habitats from Lobos Point, on the open Pacific coast of southern Baja California, Mexico, on 1 and 18 January 1999. As apical dominance influences the shape of the fronds of this species (Scrosati, 2002b), only fronds with an undamaged main apex in their main axis were collected. The dry biomass of each frond was calculated by multiplying its wet biomass by a species-specific ratio of dry biomass to wet biomass of 0.3 (Scrosati, 2000). The data hereby presented were used in a study that compared the interspecific length-biomass allometry for predominantly bidimensional seaweeds with that for microalgae and vascular plants (Scrosati, 2006b).

Saccharina latissima (Linnaeus) C. E. Lane, C. Mayes, Druehl \& G. W. Saunders (Phaeophyceae, Laminariales). Individuals of this unitary species were collected by RAS at low elevations in rocky intertidal habitats from Kitsilano Beach, Vancouver, British Columbia, Canada, on 17 April 2003. The dry biomass of each individual was calculated by multiplying its wet biomass by a species-specific ratio of dry biomass to wet biomass of 0.124 obtained by RAS. Part of the data hereby presented were used in a study that compared the interspecific length-biomass allometry for predominantly bidimensional seaweeds with that for microalgae and vascular plants (Scrosati, 2006b).

Scytosiphon lomentaria (Lyngbye) Link (Phaeophyceae, Ectocarpales). Fronds of this species were collected by HLM at low elevations in rocky intertidal habitats from Grande Greve, Nova Scotia, Canada, on 20 July 2006. The dry biomass of each frond was calculated by multiplying its wet biomass by a species-specific ratio of dry biomass to wet biomass of 0.29721 obtained by HLM.

Ulva intestinalis Linnaeus (Chlorophyta, Ulvales). Fronds of this species were collected by HLM and RAS at middle elevations in rocky intertidal habitats from the upper Antigonish Harbor, on the Gulf of St. Lawrence coast of Nova Scotia, Canada, on 23 May 2006. The dry biomass of each frond was calculated by multiplying its wet biomass by a species-specific ratio of dry biomass to wet biomass of 0.07069 obtained by HLM.

Undaria pinnatifida (Harvey) Suringar (Phaeophyceae, Laminariales). Individuals of this unitary species were collected by GNC in coastal subtidal habitats from Nuevo Gulf, Puerto Madryn, Patagonia, on the Atlantic coast in Argentina, in October and December 1997, in April, June, August, October, and December 1998, and in April, June, August, and December 1999. The dry biomass of each individual was calculated by multiplying its wet biomass by a species-specific ratio of dry biomass to wet biomass of 0.112 (Casas, 2005).

For each species, we calculated the biomass-length relationship using the data provided in Scrosati et al. (2020) following the power function $B=\alpha L^{\beta}$, where $B$ was dry biomass (in $\mathrm{mg}$ ), $L$ was length (in $\mathrm{cm}$ ), and $\alpha$ and $\beta$ were the model parameters ( $\beta$ often being called the allometric exponent). We parameterized each model through non-linear least-squares estimation (Eklöf et al., 2017) computed in Prism 6 for MacOS.

\section{SUMMARY OF THE DATA}

For the 21 studied species (Table 1), the power relationship between length and dry biomass was always significant $(P<$ 0.05 ). The fit of these relationships (adjusted $R^{2}$ ) ranged from moderate to high (Table 1). For each species, the resulting model predicts dry biomass to increase faster than length, as the allometric exponent $(\beta)$ was higher than 1 in all cases 

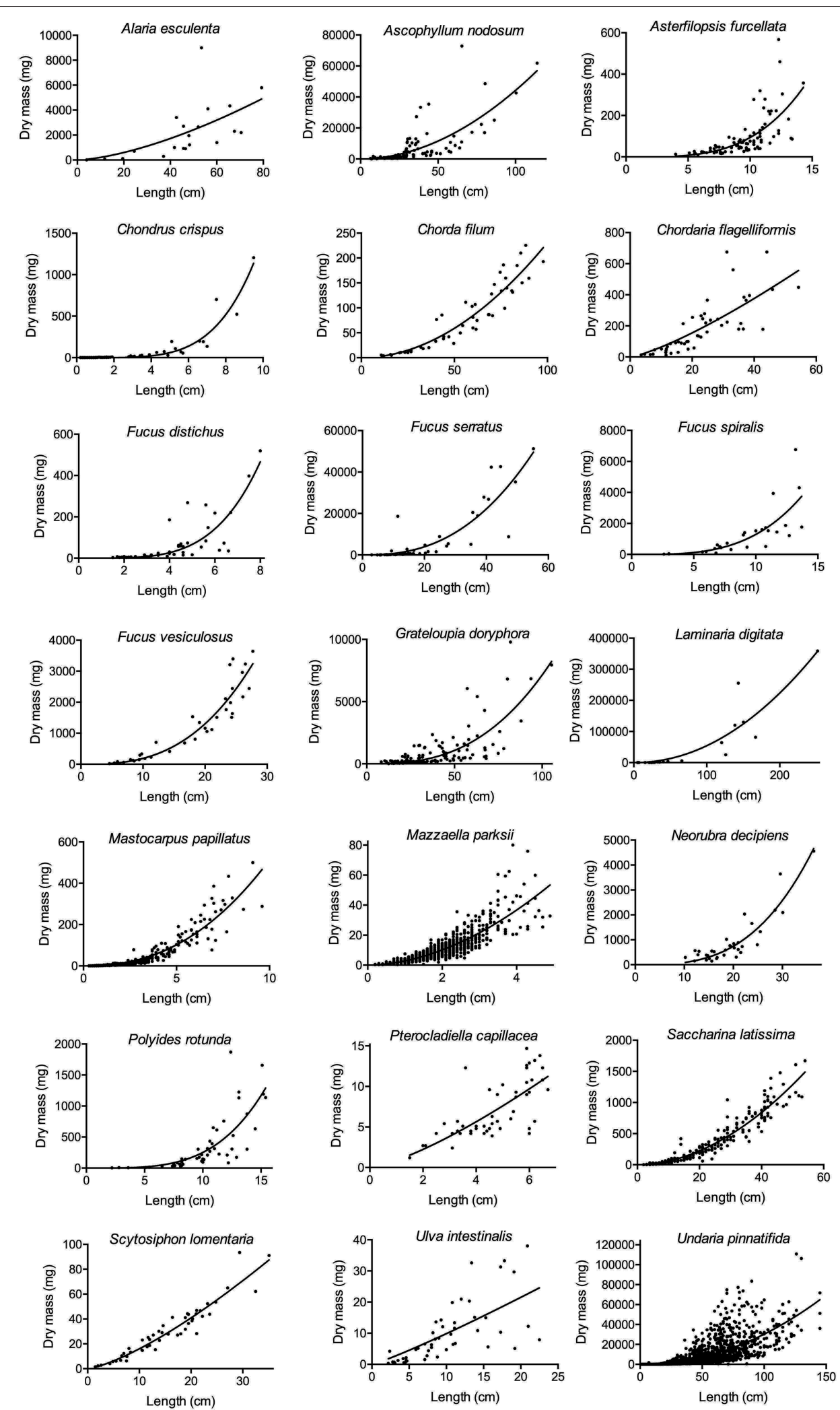

FIGURE 1 | Allometric relationships between length $(\mathrm{cm})$ and dry biomass $(\mathrm{mg})$ for the 21 studied seaweed species. 
TABLE 1 | Model parameters (with standard error, SE, in parentheses) for the power relationship between length $(L$, in $\mathrm{cm})$ and $\mathrm{dry}$ biomass $(B$, in $\mathrm{mg}), B=\alpha L^{\beta}$, for the studied seaweeds, including the adjusted $R^{2}$ and sample size for each case.

\begin{tabular}{|c|c|c|c|c|}
\hline Species & $\alpha$ (SE) & $\beta$ (SE) & Adjusted $R^{2}$ & $N$ \\
\hline Alaria esculenta & $6.212(17.850)$ & $1.525(0.701)$ & 0.36 & 20 \\
\hline Ascophyllum nodosum & $5.969(4.948)$ & $1.935(0.190)$ & 0.55 & 100 \\
\hline Asterfilopsis furcellata & $0.025(0.030)$ & $3.573(0.490)$ & 0.46 & 90 \\
\hline Chondrus crispus & $0.037(0.026)$ & $4.587(0.326)$ & 0.91 & 56 \\
\hline Chorda filum & $0.026(0.019)$ & $1.970(0.169)$ & 0.88 & 50 \\
\hline Chordaria flagelliformis & $3.348(2.214)$ & $1.280(0.187)$ & 0.61 & 50 \\
\hline Fucus distichus & $0.084(0.083)$ & $4.144(0.503)$ & 0.69 & 50 \\
\hline Fucus serratus & $2.231(2.740)$ & $2.496(0.321)$ & 0.79 & 50 \\
\hline Fucus spiralis & 0.525 (1.198) & 3.391 (0.908) & 0.56 & 27 \\
\hline Fucus vesiculosus & $0.299(0.341)$ & $2.797(0.355)$ & 0.88 & 35 \\
\hline Grateloupia doryphora & $0.025(0.024)$ & $2.730(0.227)$ & 0.58 & 135 \\
\hline Laminaria digitata & $4.503(6.614)$ & $2.041(0.276)$ & 0.84 & 26 \\
\hline Mastocarpus papillatus & $2.395(0.330)$ & $2.331(0.071)$ & 0.86 & 298 \\
\hline Mazzaella parksii & $2.807(0.101)$ & $1.854(0.033)$ & 0.77 & 1,131 \\
\hline Neorubra decipiens & $0.076(0.058)$ & $3.069(0.227)$ & 0.85 & 35 \\
\hline Polyides rotunda & $0.041(0.064)$ & $3.791(0.600)$ & 0.60 & 50 \\
\hline Pterocladiella capillacea & $0.883(0.337)$ & $1.337(0.225)$ & 0.52 & 50 \\
\hline Saccharina latissima & $0.729(0.142)$ & $1.911(0.053)$ & 0.92 & 284 \\
\hline Scytosiphon lomentaria & $0.706(0.167)$ & $1.355(0.076)$ & 0.91 & 50 \\
\hline Ulva intestinalis & $0.740(0.454)$ & $1.125(0.226)$ & 0.47 & 50 \\
\hline Undaria pinnatifida & $2.416(0.451)$ & $2.049(0.042)$ & 0.58 & 2,915 \\
\hline
\end{tabular}

All of these relationships were significant $(P<0.05)$.

(Table 1). Nonetheless, there were clear differences in biomasslength allometry across the species. For example, Ulva intestinalis exhibited a low allometric exponent (1.125), while Chondrus crispus and Fucus distichus exhibited allometric exponents approximately four times higher (Table 1). Nine of the studied species had an allometric exponent between 1 and 2 (one green, two red, and six brown algae), six species had an allometric exponent between 2 and 3 (two red and four brown algae), four species had an allometric exponent between 3 and 4 (one brown and three red algae), and two species (one red alga and one brown alga) had an allometric exponent higher than 4 (Table 1). Variability in dry biomass was often larger for high than for low values of length (Figure 1).

\section{DISCUSSION}

The biomass-length relationship for the studied seaweeds was well-described by power models. The degree of model fit varied among the species, from moderate to high. These differences were likely brought about by environmental factors that normally trigger phenotypic plasticity (Jordan and Vadas, 1972; Ateweberhan et al., 2009; Molis et al., 2015), which may have been more influential in some datasets because some sampled habitats were more heterogeneous than others and some datasets spanned different seasons (see above). Ultimately, our datasets could help as baselines to experimentally unravel the abiotic and biotic drivers of intraspecific plasticity in these species.
Regarding the interspecific differences in allometry, basic explanations relate to their morphology. For example, the species with the lowest allometric exponent, Ulva intestinalis, is long, narrow, and thin, with only two cell layers of thickness (Mathieson and Dawes, 2017). On the other extreme, the species with the two highest allometric exponents, Chondrus crispus and Fucus distichus, are branched, wide, and have several layers of cells (Scrosati, 2006b; Mathieson and Dawes, 2017), which allows them to accumulate more biomass per added unit of length. The species with intermediate values of the allometric exponent align themselves more or less accordingly along this morphological continuum. Photographs of the studied species and references describing their morphology are provided in AlgaeBase (Guiry and Guiry, 2020).

The higher variability in dry biomass often found at high length values than at low length values could be related to ontogeny. While differences among young individuals or fronds are generally small in a species, abiotic and biotic factors (temperature, competition, herbivory, etc.) often create variability in biomass accumulation patterns as individuals and fronds grow (Molis et al., 2015; Millar et al., 2020).

This paper provides novel biomass-length data for various seaweeds that add to existing datasets (Stagnol et al., 2016; Starko and Martone, 2016). Due to the theoretical interest in, and practical applications of, biomass-length relationships, we hope this study sparks renewed interest in biomass-length allometry in seaweeds, a worthwhile enterprise considering the differences in evolutionary forces shaping morphology between aquatic and terrestrial primary producers (Shurin et al., 2006). 


\section{DATA AVAILABILITY STATEMENT}

The full SST data set described in this Data Report is freely available from the figshare online repository: https://doi.org/10. 6084/m9.figshare.12777644.v1.

\section{AUTHOR CONTRIBUTIONS}

RS designed the study and wrote the manuscript. RS, HM, CC, and GC contributed through field collections and sample analyses. All authors approved the final manuscript version.

\section{REFERENCES}

Ateweberhan, M., Bruggemann, J. H., and Breeman, A. M. (2009). Seasonal changes in size structure of Sargassum and Turbinaria populations (Phaeophyceae) on tropical reef flats in the southern Red Sea. J. Phycol. 45, 69-80. doi: 10.1111/j.1529-8817.2008.00639.x

Brodeur, J. C., Damonte, M. J., Candioti, J. V., Poliserpi, M. B., D’Andrea,. M. F., and Bahl, M. F. (2020). Frog body condition: basic assumptions, comparison of methods, and characterization of natural variability with field data from Leptodactylus latrans. Ecol. Indic. 112:106098. doi: 10.1016/j.ecolind.2020.106098

Brown, J. H., Gillooly, J. F., Allen, A. P., Savage, V. M., and West, G. B. (2004). Toward a metabolic theory of ecology. Ecology 85, 1771-1789. doi: 10.1890/03-9000

Casas, G. N. (2005). Biology and ecology of Undaria pinnatifida (Phaeophyceae) in the gulf Nuevo, Argentina. (Ph.D. thesis). Bahía Blanca: Universidad Nacional del Sur.

Cetz-Navarro, N. P., Quan-Young, L. I., and Espinoza-Ávalos, J. (2015). Morphological and community changes of turf algae in competition with corals. Sci. Rep. 5:12814. doi: 10.1038/srep12814

Coulis, M., and Joly, F. X. (2017). Allometric equations for estimating fresh biomass of five soil macroinvertebrate species from neotropical agroecosystems. Eur. J. Soil Biol. 83, 18-26. doi: 10.1016/j.ejsobi.2017.09.006

de Kroon, H., and van Groenendael, J. (1997). The Ecology and Evolution of Clonal Plants. Leiden: Backhuys Publishers.

Eklöf, J., Austin, Å., Bergström, U., Donadi, S., Eriksson, B. D. H. K., Hansen, J., et al. (2017). Size matters: relationships between body size and body mass of common coastal, aquatic invertebrates in the Baltic Sea. PeerJ 5:e2906. doi: $10.7717 /$ peerj.2906

Guiry, M. D., and Guiry, G. M. (2020). AlgaeBase. Available online at: https://www. algaebase.org (accessed October 07, 2020).

Jordan, A. J., and Vadas, R. L. (1972). Influence of environmental parameters on intraspecific variation in Fucus vesiculosus. Mar. Biol. 14, 248-252.

Kleyer, M., Trinogga, J., Cebrián-Piqueras, M. A., Trenkamp, A., Fløjgaard, C., Ejrnæs, R., et al. (2019). Trait correlation network analysis identifies biomass allocation traits and stem specific length as hub traits in herbaceous perennial plants. J. Ecol. 107, 829-842. doi: 10.1111/1365-2745.13066

Makarieva, A. M., Gorshkov, V. G., and Li, B. L. (2005). Revising the distributive networks models of West, Brown and Enquist (1997) and Banavar, Maritan and Rinaldo (1999): metabolic inequity of living tissues provides clues for the observed allometric scaling rules. J. Theor. Biol. 237, 291-301. doi: 10.1016/j.jtbi.2005.04.016

Marquet, P. A., Quiñones, R. A., Abades, S., Labra, F., Tognelli, M., Arim, M., et al. (2005). Scaling and power laws in ecological systems. J. Exp. Biol. 208, 1749-1769. doi: $10.1242 /$ jeb.01588

Martin, C. A., Proulx, R., and Magnan, P. (2014). The biogeography of insects' length-dry mass relationships. Insect Conserv. Diver. 7, 413-419. doi: 10.1111 /icad.12063

Mathieson, A. C., and Dawes, C. J. (2017). Seaweeds of the Northwest Atlantic. Amherst and Boston, MA: University of Massachusetts Press.

\section{FUNDING}

This study was funded by grants awarded to RS by the Natural Sciences and Engineering Research Council of Canada (NSERC Discovery Grant \#311624), the Canada Research Chairs program (CRC grant \#210283), and the Canada Foundation for Innovation (CFI Leaders Opportunity Grant \#202034).

\section{ACKNOWLEDGMENTS}

We thank Elizabeth MacPherson for field assistance and three reviewers for constructive comments on an earlier version of this paper.

Millar, R. V., Houghton, J. D. R., Elsäßer, B., Mensink, P. J., and Kregting, L. (2020). Influence of waves and currents on the growth rate of the kelp Laminaria digitata (Phaeophyceae). J. Phycol. 56, 198-207. doi: 10.1111/jpy. 12943

Molis, M., Scrosati, R. A., El-Belely, E. F., Lesniowski, T., and Wahl, M. (2015). Wave-induced changes in seaweed toughness entail plastic modifications in snail traits maintaining consumption efficacy. J. Ecol. 103, 851-859. doi: 10.1111/1365-2745.12386

Niklas, K. J., and Enquist, B. J. (2001). Invariant scaling relationships for interspecific plant biomass production rates and body size. Proc. Natl. Acad. Sci. U.S.A. 98, 2922-2927. doi: 10.1073/pnas.041590298

Pereira, T. R., Engelen, A. H., Pearson, G. A., Valero, M., and Serrão, E. A. (2017). Population dynamics of temperate kelp forests near their low-latitude limit. Aquat. Bot. 139, 8-18. doi: 10.1016/j.aquabot.2017.02.006

Rivera, M., and Scrosati, R. (2008). Self-thinning and size inequality dynamics in a clonal seaweed (Sargassum lapazeanum). J. Phycol. 44, 45-49. doi: 10.1111/j.1529-8817.2007.00427.x

Scrosati, R. (1998). Population structure and dynamics of the clonal alga Mazzaella cornucopiae (Rhodophyta, Gigartinaceae) from Barkley Sound, Pacific coast of Canada. Bot. Mar. 41, 483-493. doi: 10.1515/botm.1998.41.1-6.483

Scrosati, R. (2000). The interspecific biomass-density relationship for terrestrial plants: where do clonal red seaweeds stand and why? Ecol. Lett. 3, 191-197. doi: 10.1046/j.1461-0248.2000.00133.x

Scrosati, R. (2002a). An updated definition of genet applicable to clonal seaweeds, bryophytes, and vascular plants. Basic Appl. Ecol. 3, 97-99. doi: 10.1078/1439-1791-00106

Scrosati, R. (2002b). Morphological plasticity and apparent loss of apical dominance following the natural loss of the main apex in Pterocladiella capillacea (Rhodophyta, Gelidiales) fronds. Phycologia 41, 96-98. doi: 10.2216/i0031-8884-41-1-96.1

Scrosati, R. (2005). Review of studies on biomass-density relationships (including self-thinning lines) in seaweeds: main contributions and persisting misconceptions. Phycol. Res. 53, 224-233. doi: 10.1111/j.1440-1835.2005.tb00375.x

Scrosati, R. (2006a). Crowding in clonal seaweeds: does self-thinning occur in Mastocarpus papillatus before stand biomass peaks? Aquat. Bot. 84, 233-238. doi: 10.1016/j.aquabot.2005.10.003

Scrosati, R. (2006b). Length-biomass allometry in primary producers: predominantly bidimensional seaweeds differ from the "universal" interspecific trend defined by microalgae and vascular plants. Can. J. Bot. 84, 1159-1166. doi: 10.1139/b06-077

Scrosati, R., and DeWreede, R. E. (1997). Dynamics of the biomass-density relationship and frond biomass inequality for Mazzaella cornucopiae (Rhodophyta, Gigartinaceae): implications for the understanding of frond interactions. Phycologia 36, 506-516. doi: 10.2216/i0031-8884-36-6506.1

Scrosati, R., and DeWreede, R. E. (1998). The impact of frond crowding on frond bleaching in the clonal intertidal alga Mazzaella cornucopiae (Rhodophyta) from British Columbia, Canada. J. Phycol. 34, 228-232. doi: 10.1046/j.1529-8817.1998.340228.x 
Scrosati, R. A., MacDonald, H. L., Córdova, C. A., and Casas, G. N. (2020). Length and Biomass Data for Seaweeds. figshare dataset. Avaialble online at: https://doi. org/10.6084/m9.figshare.12777644.v1 (accessed October 07, 2020).

Shurin, J. B., Gruner, D. S., and Hillebrand, H. (2006). All wet or dried up? Real differences between aquatic and terrestrial food webs. Proc. R. Soc. B 273, 1-9. doi: 10.1098/rspb.2005.3377

Sohlström, E. H., Marian, L., Barnes, A. D., Haneda, N. F., Scheu, S., Rall, B. C., et al. (2018). Applying generalized allometric regressions to predict live body mass of tropical and temperate arthropods. Ecol. Evol. 8, 12737-12749. doi: 10.1002/ece3.4702

Stagnol, D., Macé, M., Destombe, C., and Davoult, D. (2016). Allometric relationships for intertidal macroalgae species of commercial interest. J. Appl. Phycol. 28, 3407-3411. doi: 10.1007/s10811-0160860-1

Starko, S., and Martone, P. T. (2016). An empirical test of 'universal' biomass scaling relationships in kelps: evidence of convergence with seed plants. New Phytol. 212, 719-729 doi: 10.1111/nph.14120

Steneck, R. S., and Dethier, M. N. (1994). A functional-group approach to the structure of algal-dominated communities. Oikos 69, 476-498. doi: $10.2307 / 3545860$

Turnbull, M. S., George, P. B. L., and Lindo, Z. (2014). Weighing in: size spectra as a standard tool in soil community analyses. Soil Biol. Biochem. 68, 366-372. doi: 10.1016/j.soilbio.2013.10.019
Watt, C. A., and Scrosati, R. A. (2013). Bioengineer effects on understory species richness, diversity, and composition change along an environmental stress gradient: experimental and mensurative evidence. Estuar. Coast. Shelf Sci. 123, 10-18. doi: 10.1016/j.ecss.2013.02.006

West, G. B., Brown, J. H., and Enquist, B. J. (1999). A general model for the structure and allometry of plant vascular systems. Nature 400, 664-667. doi: $10.1038 / 23251$

Yuen, J. Q., Fung, T., and Ziegler, A. D. (2016). Review of allometric equations for major land covers in SE Asia: uncertainty and implications for above- and below-ground carbon estimates. For. Ecol. Manag. 360, 323-340. doi: 10.1016/j.foreco.2015.09.016

Conflict of Interest: The authors declare that the research was conducted in the absence of any commercial or financial relationships that could be construed as a potential conflict of interest.

Copyright (C) 2020 Scrosati, MacDonald, Córdova and Casas. This is an open-access article distributed under the terms of the Creative Commons Attribution License (CC $B Y)$. The use, distribution or reproduction in other forums is permitted, provided the original author(s) and the copyright owner(s) are credited and that the original publication in this journal is cited, in accordance with accepted academic practice. No use, distribution or reproduction is permitted which does not comply with these terms. 